\title{
In Vitro Rumen Fermentation of Ration Supplemented with Protected Vegetable Oils
}

\author{
N. Hidayah ${ }^{\mathrm{a}}$, S. Suharti ${ }^{\mathrm{b}}$, \& K. G. Wiryawan ${ }^{\mathrm{b}^{*}}$ \\ aStudy Program of Animal Nutrition and Feed Science, Graduate School, Bogor Agricultural University \\ ${ }^{b}$ Department of Nutrition Science and Feed Technology, Faculty of Animal Science, Bogor Agricultural University \\ Jln. Agatis, Kampus IPB Darmaga, Bogor 16680, Indonesia \\ (Received 01-07-2014; Reviewed 16-07-2014; Accepted 30-07-2014)
}

\begin{abstract}
This experiment was designed to evaluate the effects of protected vegetable oils supplementation on in vitro fermentation characteristics, rumen microbial population, and methane production in cattle. The treatments were arranged in a complete randomized block design involving 2 factors i.e. oil type (sesame, canola, and flaxseed) and protection methods (non protected, calcium soap, and microencapsulation). Variables observed were rumen $\mathrm{pH}, \mathrm{N}-\mathrm{NH}_{3}$, total and molar proportion of VFA, dry matter and organic matter digestibility, population of protozoa and total bacteria, methane production, and hydrogen balance. Data were tested using Analysis of Variance (ANOVA) and the differences among treatments means were examined by Duncan Multiple Range Test. The oil type did not affect all variables measured. The protection method using microencapsulation significantly increased $\mathrm{N}-\mathrm{NH}_{3}$ concentration. There was an interaction between oil type and protection method on total VFA concentration, molar proportion of VFA, and methane production. The supplementation of calcium soap-flaxseed oil significantly increased total VFA production, while the supplementation of microencapsulated flaxseed oil had the highest propionate concentration and $\mathrm{H}_{2}$ utilization, the lowest A:P ratio, and methane production. It is concluded that microencapsulated flaxseed oil was the best treatment to optimize rumen fermentation.
\end{abstract}

Key words: fermentation characteristics, methane, protection methods, vegetable oil, rumen microbe

\section{ABSTRAK}

Penelitian ini dirancang untuk menganalisis pengaruh penambahan minyak nabati terproteksi terhadap karakteristik fermentasi, populasi mikroba rumen, dan produksi metan ternak ruminansia secara in vitro. Rancangan percobaan yang digunakan dalam penelitian ini adalah rancangan acak kelompok pola faktorial dengan 2 faktor dan 3 ulangan: jenis minyak nabati (wijen, kanola, dan flaxseed) dan jenis metode proteksi (tanpa proteksi, sabun kalsium, dan mikroenkapsulasi). Variabel yang diamati meliputi nilai $\mathrm{pH}$ rumen, konsentrasi $\mathrm{NH}_{3}$, produksi VFA total dan parsial, kecernaan bahan kering dan bahan organik, populasi protozoa dan bakteri total, dan produksi metan. Data dianalisa menggunakan analisis ragam (ANOVA) dan perbedaan nyata antar perlakuan dianalisa menggunakan uji Duncan. Penggunaan jenis minyak nabati yang berbeda tidak berpengaruh terhadap karakteristik fermentasi, populasi mikroba rumen, produksi metan, dan keseimbangan hidrogen. Metode proteksi mikroenkapsulasi nyata meningkatkan konsentrasi $\mathrm{NH}_{3}$ rumen. Terdapat interaksi antara jenis minyak nabati dan metode proteksi pada produksi VFA total, proporsi VFA parsial, dan produksi metan. Suplementasi minyak flaxseed yang diproteksi dengan metode sabun kalsium sangat nyata meningkatkan VFA total. Suplementasi minyak flaxseed yang diproteksi dengan metode mikroenkapsulasi menghasilkan proporsi propionat dan penggunaan $\mathrm{H}_{2}$ tertinggi serta rasio A:P dan produksi metan terendah. Kesimpulan dari penelitian ini yaitu bahwa minyak flaxseed dan mikroenkapsulasi merupakan jenis minyak dan metode proteksi terbaik dalam mengoptimalkan fermentasi rumen.

Kata kunci: karakteristik fermentasi, metan, metode proteksi, minyak nabati, mikroba rumen

*Corresponding author:

E-mail: k.wiryawan@yahoo.com 


\section{INTRODUCTION}

National meat production from beef cattle could not fulfill the demand and there is still deficit about 400000 ton in 2014. Program of increasing beef cattle population and productivity by $23 \%$ in 2014 is the Government target to suppress import of beef cattle. The target should be followed with improving of beef quality. Beef is red meat containing high saturated fatty acids (SFA) associated with the risk of cardiovascular and cancer diseases when consumed in high level. High SFA content in beef is normally occurs due to biohydrogenation process in the rumen which transforms the PUFA to SFA. This rumen biohydrogenation process is a detoxification mechanism to avoid bacteriostatic effects of unsaturated fatty acids which could disrupt membrane integrity and decrease growth of microbes. Butyrivibrio fibrisolvens is a major microbe which plays role in this biohydrogenation process (Maia et al., 2010).

Previous studies showed that supplementation of vegetable oil (high PUFA content) could decrease saturated fatty acid content and increase unsaturated fatty acid content in beef. Some potential vegetable oils to use are sesame, canola, and flaxseed oil (Manso et al., 2005; Aharoni et al., 2005; Beauchemin et al., 2007). Supplementation of $10 \%$ flaxseed oil in cattle ration significantly increased PUFA and omega 3 proportion on intramuscular fat (Kim et al., 2009). Duckett \& Gillis (2010) reported that supplementation of $4 \%$ canola oil in ration significantly increased $(\mathrm{P}<0.001)$ oleic acid, linoleic acid, and decreased palmitic acid on biohydrogenation process than corn oil. Supplementation of $4 \%$ flaxseed oil in the form of non protected, lipase-treated, or soapstock in ration increased linoleic acid concentration in beef tissue (Quinn et al. 2008). However, this oil needs to be protected prior to supplementation to avoid biohydrogenation process by rumen microbes, to decrease rumen microbial growth and activity, and to improve feed digestibility. Some protection methods that can be applied are calcium soap (Block et al., 2005; Wynn et al., 2006; Huang et al., 2009) and microencapsulation (Kanakdande et al., 2007; Calvo et al., 2010; Agnihotri et al., 2012). However, optimization for rumen fermentation, oil type and protection method should be determined. The objective of this research was to evaluate the effects of supplementation of three kinds of vegetable oils (sesame, canola, and flaxseed) protected using calcium soap and microencapsulation on in vitro fermentation characteristics, rumen microbial population, methane production, and hydrogen balance.

\section{MATERIALS AND METHODS}

\section{Preparation of Calcium Soap and Microencapsulation}

The sesame oil, canola oil, and flaxseed oil were produced by MH Farm Bogor Company, Golden Bridge, and Green Tosca, respectively. Calcium soap from these three kinds of vegetable oils was made according to the method by Kumar et al. (2006). The main ingredients for calcium soap were $\mathrm{NaOH}$ (to hydrolize the fatty acids of vegetable oil) and $\mathrm{CaCl}_{2}$. and $\mathrm{CaCl}_{2}$. Sodium hydroxide solution (in line with saponification value) was added into hot vegetable oil, heated and stirred on a hotplate until the fat was completely dissolved. Calcium chloride $(2.35 \mathrm{~g})$ were dissolved in $4.7 \mathrm{~mL}$ of water and then added slowly into the water soluble soap while being stirred to aid the precipitation of calcium soap. Calcium soap was then dried overnight in a oven at $60^{\circ} \mathrm{C}$.

The microencapsulation was done according to the method by Calvo et al. (2010). Sodium caseinate (protein source) from Sigma Aldrich (Singapore) and lactose (carbohydrate source) of commercial grade were used for microencapsulation wall. The process included making emulsion, mixing the wall materials, and mixing it with oil until homogenous. The ratio of oil and wall materials used was $1 \%$ (oil): $2 \%$ ( $1 \%$ sodium caseinate and $1 \%$ lactose). The emulsion prepared was spray dried using a laboratory scale Buchi spray drier (Mini Spray drier B190) with 100 mesh or $0.149 \mathrm{~mm}$ of nozzle diameter. The pressure of compressed air for the flow of the spray was adjusted to 5 bars. The inlet and outlet air temperatures were maintained at $175 \pm 5{ }^{\circ} \mathrm{C}$ and $55 \pm 5{ }^{\circ} \mathrm{C}$, respectively.

\section{In Vitro Fermentation}

In vitro fermentation was conducted according to the method of Tilley and Terry (1963). Into each $100 \mathrm{~mL}$ fermentation tube, $500 \mathrm{mg}$ substrate, $40 \mathrm{~mL} \mathrm{McDougall}$ buffer, and $10 \mathrm{~mL}$ rumen fluid were added at conducted at $39{ }^{\circ} \mathrm{C}$. The substrate contained $60 \%$ king grass and $40 \%$ concentrate mixture (cassava by product, wheat pollard, soybean meal, coconut cake meal, molasses, $\mathrm{CaCO}_{3^{\prime}}$ premix, urea, and $4 \%$ vegetable oil either non-protected, calcium soap, or microencapsulated) with $15 \%-17 \%$ CP and $69 \%-74 \%$ TDN (Table 1). The rumen fluid for this experiment was collected after $3 \mathrm{~h}$ morning feeding from the 3 rumens fistulated Ongole crossbred beef cattle with Ethical Approval from Animal Care and Use Committee (AUAC) 01-2013b IPB. Samples from aliquol were taken after $4 \mathrm{~h}$ incubation for $\mathrm{pH}, \mathrm{VFA}, \mathrm{NH}_{3}$, protozoa, total bacterial analysis and after $48 \mathrm{~h}$ incubation for dry matter and organic matter digestibility analysis.

\section{Sampling and Measurement}

The rumen's $\mathrm{pH}$ was measured with $\mathrm{pH}$ meter. Ammonia (N-NH3) concentration was measured by microdiffusion conway method. Total VFA concentration and molar proportion of VFA were analyzed using gas chromatography (GC 8A, Shimadzu Crop., Kyoto, Japan, Capillary column type containing 10\% SP-1200, $1 \% \mathrm{H}_{3} \mathrm{PO}_{4}$ on $80 / 100$ Cromosorb WAW and nitrogen as gas carrier). Prior to analysis, the $\mathrm{pH}$ of rumen liquid from in vitro incubation was adjusted to 3-4 with $\mathrm{H}_{2} \mathrm{SO}_{4}$. The dry matter digestibility (DMD) and organic matter digestibility (OMD) were measured using Tilley \& Terry (1963) method. Protozoa population was determined using Fuch Rosenthal Counting Chamber ( $4 \times 4 \times 0.2 \mathrm{~mm})$ under a microscope $(40 \times)$. The $0.5 \mathrm{~mL}$ liquid sample from 4 $\mathrm{h}$ incubation tubes were mixed with $2 \mathrm{~mL}$ methyl green formaldehyde saline solution. Population of total bacteria were quantified by Ogimoto \& Imai (1981) method used BHI media and roller tube method. Methane pro- 
Table 1. Chemical composition of experimental subtrate (dry metter basis) with $60 \%$ king grass forage and $40 \%$ concentrate mixture

\begin{tabular}{lrrrrrrrrr}
\hline Nutrient (\%) & R1 & R2 & R3 & \multicolumn{1}{c}{ R4 } & \multicolumn{1}{c}{ R5 } & \multicolumn{1}{c}{ R6 } & \multicolumn{1}{l}{ R7 } & R8 & R9 \\
\hline Ash & 7.67 & 7.26 & 6.78 & 7.51 & 7.42 & 7.54 & 8.08 & 7.24 & 9.09 \\
EE & 5.43 & 5.60 & 5.41 & 4.92 & 4.59 & 5.40 & 4.43 & 3.87 & 3.56 \\
CP & 15.66 & 16.10 & 16.52 & 16.69 & 16.05 & 15.15 & 16.67 & 17.93 & 17.58 \\
CF & 22.89 & 23.86 & 24.17 & 23.33 & 24.02 & 23.04 & 22.74 & 23.65 & 23.46 \\
BETN & 48.35 & 47.18 & 47.12 & 47.55 & 47.93 & 48.88 & 48.08 & 47.31 & 46.31 \\
TDN & 74.05 & 72.60 & 72.70 & 73.04 & 71.08 & 73.78 & 72.66 & 71.34 & 69.12 \\
\hline
\end{tabular}

Note: 1) Estimation of TDN by Hartadi (1980) formula: TDN= $92.464-(3.338 \times C F)-(6.945 \times \mathrm{EE})-(0.762 \times \mathrm{Beta}-\mathrm{N})+(1.115 \times \mathrm{CP})+(0.031 \times \mathrm{CF} 2)-(0.133$ $\left.\times \mathrm{EE}^{2}\right)+(0.036 \times \mathrm{CF} \times$ Beta-N $)+(0.207 \times \mathrm{EE} \times$ Beta-N $\left.)+(0.1 \times \mathrm{EE} \times \mathrm{CP})-(0.022 \times \mathrm{EE} \times \mathrm{CP}) ; 2\right) \mathrm{R} 1=4 \%$ non protected sesame oil; R2=4\% non protected canola oil; R3=4\% non protected flaxseed oil; R4=4\% calcium soap-sesame; R5=4\% calcium soap-canola; R6= $\%$ calcium soap-flaxseed; $\mathrm{R} 7=4 \%$ microencapsulation-sesame, $\mathrm{R} 8=4 \%$ microencapsulation-canola; R9: 4\% microencapsulation-flaxseed.

duction was estimated from molar proportions of VFA according to Moss et al. (2000) $\left(\mathrm{CH}_{4}=0.45 \mathrm{C}_{2}-0.275 \mathrm{C}_{3}\right.$ $\left.+0.40 \mathrm{C}_{4}\right)$, meanwhile hydrogen balance was estimated from molar proportion of VFA according to Mitsumori et al. $(2012)\left[2 \mathrm{HP}\right.$ (Hydrogen production) $=2 \times \mathrm{C}_{2}+\mathrm{C}_{3}+4 \mathrm{x}$ $\mathrm{C}_{4}+2 \times \mathrm{Ci}_{5}+2 \times \mathrm{C}_{5}$ ] and [2HUS (Hydrogen utilization) $=$ $\left.2 \times \mathrm{C}_{3}+2 \times \mathrm{C}_{4}+\mathrm{C}_{5}\right]$.

\section{Statistical Analysis}

The experiment was conducted in a factorial randomized block design with 2 factors and 3 replicates. The first factor was kinds of vegetable oil (sesame, canola, and flaxseed) and the second factor was protection methods (non protected, calcium soap, and microencapsulation). Data were tested using Analysis of Variance (ANOVA) and the differences among treatments' means were examined by Duncan Multiple Range Test (Steel \& Torrie, 1995).

\section{RESULTS AND DISCUSSION}

\section{Characteristics of Calcium Soap and Microencapsulation Products}

The calcium soap products were a little mushy so a carrier was needed to be able to use it, while the micro- encapsulation product was in the form of powder and was very small in size (Figure 1). The yield of calcium soap product from sesame, canola, and flexseed oils were $95.60 \%, 96.81 \%$, and $97.30 \%$, respectively, while microencapsulation of sesame, canola, and flexseed oils were $64.17 \%, 53.74 \%$, and $51.64 \%$, respectively. Similar finding was reported by Calvo et al. (2010) in which microencapsulation yield was reported at $49.49 \%$ with the ratio of the coating material from combination of carbohydrates (lactose) and protein (sodium caseinate) of 1:1 and 1:2 for core material and coating material. Microencapsulation yield was lower than calcium soap yield because proportion of oil and coating used in microencapsulation was 1:2 while calcium soap was 9:1.

\section{Fermentation Characteristics and Population of Rumen Microbes}

There were no interaction between type of vegetable oils and the protection method on rumen $\mathrm{pH}$, ammonia $\left(\mathrm{NH}_{3}\right)$ concentration, dry matter digestibility (DMD) and organic matter digestibility (OMD), protozoa and total bacterial population. Kinds of vegetable oil did not affect fermentation characteristic and rumen microbe population. Supplementation of non protected vegetable oil significantly decreased $(\mathrm{P}<0.05)$ rumen $\mathrm{pH}$. Supplementation of microencapsulated vegetable oil



(a) Calcium soap - sesame

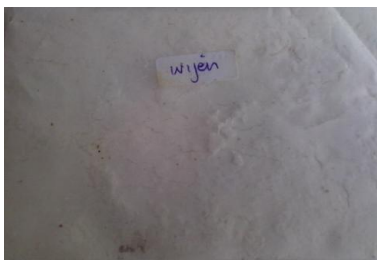

(d) Microencapsulation-sesame



(b) Calcium soap - canola

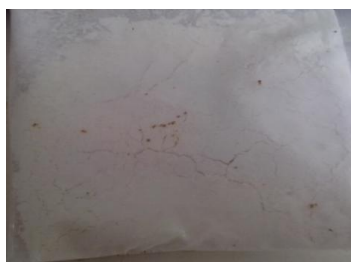

(e) Microencapsulation-canola

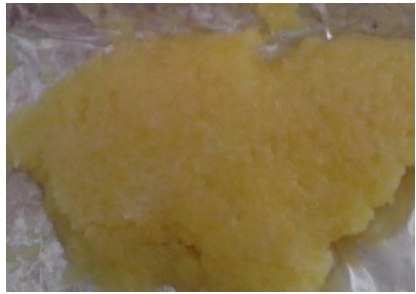

(c) Calcium soap - Falxseed



(f) Microencapsulation-Falxseed

Figure 1. Characteristic of calcium soap and microencapsulation product from sesame oil, canola oil, and flaxseed oil. 
significantly increased $(\mathrm{P}<0.05) \quad \mathrm{N}-\mathrm{NH}_{3}$ concentration. Supplementation of vegetable oil without and with protection using calcium soap or microencapsulation methods did not affect dry matter digestibility (DMD) and organic matter digestibility (OMD), protozoa and total bacterial population (Table 2).

Decrease in rumen $\mathrm{pH}$ value after supplementation of non-protected vegetable oil was presumably due to less rumen microbial activity, especially protozoa. Jenkins (1993) stated that supplementation of fat on feed can disturb membrane and cellular function, activity and expression of microbial hydrolytic enzymes. Decrease in protozoa activity will reduce its ability to stabilize rumen $\mathrm{pH}$. Protozoa has ability to stabilize rumen $\mathrm{pH}$ value and decrease redox potential of rumen digestibility. Similar finding was reported by Bhatt et al. (2011) in which supplementation of coconut oil at $7.5 \%$ on feed of Malpura sheep in vivo tend to decrease the rumen $\mathrm{pH}$ value $(\mathrm{P}=0.108)$ linearly compared to supplementation of coconut oil at $2.5 \%$ and $5 \%$ (6.31 to 6.62). Different result was reported by Jalc et al. (2007) in which supplementation of PUFA (oleic, linoleic, and $\alpha$-linolenic) at 3,5\% on diet containing $80 \%$ lucerne and $20 \%$ barley did not influence rumen $\mathrm{pH}$ value (6.73-6.93). The differences in these responses might be due to differences of the level and profile concentration of fatty acid sources used in these researches. Rumen $\mathrm{pH}$ value in this research was 6.00-6.33 which was still considered normal. Dehority (2005) reported that normally rumen $\mathrm{pH}$ value was 5.4-7.8.
Increasing ammonia $\left(\mathrm{N}-\mathrm{NH}_{3}\right)$ concentration in response to supplementation of microencapsulated vegetable oil was caused by sodium caseinate as a coating material that increased crude protein content of microencapsulation product $(27.64 \%-30.22 \%)$. This microencapsulation product would increase protein content of the ration $(19.49 \%-22.64 \%)$, so that linearly increasing ammonia production. McDonald et al. (2002) stated that the amount of protein in ration is one of the factors that influence ammonia production. Concentration of ammonia with addition of non protected oil lower than microencapsulation protection. This was presumble because addition at $4 \%$ non protected oil has started disturbing rumen microbial activity, especially proteolytic bacteria and protozoa. Hristov et al. (2004) reported that concentration of ammonia is highly correlated with the total number of protozoa and bacterial activity in the rumen. The addition of fat especially MCFA (Medium Chain Fatty Acid) decreased the growth and activity of the protozoa, proteolysis and ammonia concentrations in vitro and inhibit the activity of polysaccharide degradation.

Supplementation of non protected vegetable oil at $4 \%$ did not disturb feed digestibility (DMD and OMD) and rumen microbial population (protozoa and bacteria), but it started to show a decrease in the activity. This might be due to the low level of vegetable oil added on concentrate. Purushothaman et al. (2008) reported that addition at $6 \%$ calcium salt of palm oil in the concentrate mixture of lactating crossbred cows did not decreased dry maetter and organic metter digestibility. Supplementation of red palm oil in the form

Table 2. Fermentation characteristic and rumen microbe population with different types of vegetable oil and protections method

\begin{tabular}{|c|c|c|c|c|c|}
\hline Variables & Types of vegetable oil & Not protected & Calcium soap & Microencapsulation & $\begin{array}{c}\text { Mean types of } \\
\text { vegetable oil }\end{array}$ \\
\hline \multirow{4}{*}{ Rumen pH } & Sesame & $5.89 \pm 0.16$ & $6.25 \pm 0.27$ & $6.27 \pm 0.25$ & $6.14 \pm 0.22$ \\
\hline & Canola & $6.03 \pm 0.09$ & $6.24 \pm 0.28$ & $6.33 \pm 0.28$ & $6.20 \pm 0.20$ \\
\hline & Flaxseed & $6.09 \pm 0.04$ & $6.25 \pm 0.26$ & $6.38 \pm 0.27$ & $6.24 \pm 0.19$ \\
\hline & Mean of Protections Method & $6.00 \pm 0.10^{\mathrm{b}}$ & $6.25 \pm 0.27^{\mathrm{a}}$ & $6.33 \pm 0.26^{\mathrm{a}}$ & \\
\hline \multirow[t]{4}{*}{$\mathrm{N}-\mathrm{NH}_{3}(\mathrm{mM})$} & Sesame & $8.26 \pm 0.64$ & $8.28 \pm 0.55$ & $9.90 \pm 1.40$ & $8.81 \pm 1.15$ \\
\hline & Canola & $7.23 \pm 1.53$ & $7.87 \pm 1.84$ & $9.12 \pm 1.02$ & $8.07 \pm 1.55$ \\
\hline & Flaxseed & $7.96 \pm 0.58$ & $9.06 \pm 0.86$ & $10.08 \pm 1.07$ & $9.03 \pm 1.18$ \\
\hline & Mean of Protections Method & $7.81 \pm 0.99^{b}$ & $8.40 \pm 1.17^{\mathrm{b}}$ & $9.70 \pm 1.11^{\mathrm{a}}$ & \\
\hline \multirow[t]{4}{*}{$\operatorname{DMD}(\%)$} & Sesame & $62.30 \pm 5.10$ & $64.10 \pm 1.57$ & $65.68 \pm 3.75$ & $64.03 \pm 3.47$ \\
\hline & Canola & $66.31 \pm 1.38$ & $64.64 \pm 5.22$ & $63.93 \pm 4.85$ & $64.96 \pm 3.82$ \\
\hline & Flaxseed & $63.67 \pm 0.20$ & $66.01 \pm 1.76$ & $64.22 \pm 4.50$ & $64.64 \pm 2.15$ \\
\hline & Mean of Protections Method & $64.09 \pm 2.22$ & $64.92 \pm 2.85$ & $64.61 \pm 4.36$ & \\
\hline \multirow[t]{4}{*}{ OMD $(\%)$} & Sesame & $60.50 \pm 5.41$ & $61.43 \pm 3.62$ & $62.13 \pm 0.34$ & $61.35 \pm 3.33$ \\
\hline & Canola & $65.49 \pm 1.80$ & $65.40 \pm 1.51$ & $62.85 \pm 4.34$ & $64.58 \pm 2.79$ \\
\hline & Flaxseed & $61.68 \pm 1.51$ & $64.66 \pm 2.14$ & $63.23 \pm 4.71$ & $63.19 \pm 2.99$ \\
\hline & Mean of Protections Method & $62.56 \pm 3.71$ & $63.83 \pm 2.89$ & $62.74 \pm 3.24$ & \\
\hline \multirow{4}{*}{$\begin{array}{l}\text { Protozoa } \\
\text { (Log Cell/mL) }\end{array}$} & Sesame & $3.91 \pm 0.45$ & $4.03 \pm 0.03$ & $3.98 \pm 0.06$ & $3.97 \pm 0.23$ \\
\hline & Canola & $4.00 \pm 0.17$ & $4.20 \pm 0.05$ & $4.28 \pm 0.05$ & $4.16 \pm 0.16$ \\
\hline & Flaxseed & $4.10 \pm 0.30$ & $4.40 \pm 0.29$ & $4.13 \pm 0.54$ & $4.21 \pm 0.37$ \\
\hline & Mean of Protections Method & $4.00 \pm 0.30$ & $4.21 \pm 0.22$ & $13.13 \pm 0.30$ & \\
\hline \multirow{4}{*}{$\begin{array}{l}\text { Bakteri } \\
\text { (Log Cell/mL) }\end{array}$} & Sesame & $7.28 \pm 1.93$ & $6.66 \pm 1.47$ & $7.25 \pm 2.45$ & $7.06 \pm 1.75$ \\
\hline & Canola & $6.87 \pm 0.68$ & $7.49 \pm 1.26$ & $6.92 \pm 0.82$ & $7.09 \pm 0.88$ \\
\hline & Flaxseed & $7.29 \pm 0.66$ & $7.79 \pm 0.54$ & $6.69 \pm 0.98$ & $7.26 \pm 0.80$ \\
\hline & Mean of Protections Method & $7.14 \pm 1.10$ & $7.31 \pm 1.12$ & $6.95 \pm 1.40$ & \\
\hline
\end{tabular}

Note : Means in the same row with different superscript differ significantly $(\mathrm{P}<0.05)$. 
calcium soap at $15 \%$ on ration contained 59.5 parts sorghum straw and 40.5 parts concentrate mixture did not disturb dry metter and organic metter digestibility on Decani sheep (Ramana et al., 2003). Bhatt et al. (2011) reported that protozoa population decreased linearly $(\mathrm{P}=0.006)$ alongside with the increase in coconut oil added $\left(0 \%: 99.7 \times 10^{4}\right.$ cells $\left./ \mathrm{ml}\right),\left(2.5 \%: 74.6 \times 10^{4}\right.$ cells $\left./ \mathrm{ml}\right)$, (5\% : $57.7 \times 10^{4}$ cells $\left./ \mathrm{mL}\right)$, and $\left(7.5 \%: 8.6 \times 10^{4}\right.$ cells $\left./ \mathrm{ml}\right)$. In this study, supplementation of non protected vegetable oil at $4 \%$ did not significantly decrease protozoa population, but the population was still lower compared to that of vegetable oil protected with calcium soaps or microencapsulation. Sitoresmi et al. (2009) reported that supplementation of oil at $5.0 \%$ gave significant effect in decreasing protozoa population. Different response was reported by Adawiyah (2007) in which supplementation of non-protected fish oil at $1.5 \%$ was highly significant in decreasing $(\mathrm{P}<0.01)$ total bacterial population, but the population did not decrease in response to $3 \%$ supplementation of fish oil protected with calcium soaps (1.71 and $3: 53 \times 109 / \mathrm{mL}$ ). The supplementation of non protected fish oil at low level significantly decreased total bacterial population. Fish oil contains EPA and DHA which are the most toxic component in disturbing the growth of rumen bacteria. Maia et al. (2007) stated that EPA and DHA were not metabolized by bacteria so that EPA and DHA were more toxic than linoleic (LA) and linolenic acid (LNA). The addition sesame oil decreased the lowest protozoa population than others. This was presumably the highest lauric acid content in sesame oil can reduced protozoa. Hristov et al. (2004) reported that lauric acid was the most toxic of MCFA to the protozoa. Lauric acid increased the sensitivity of microbial cell wall structure so can inhibit of the activity ciliate protozoa and gram-positive archaea (Machmuller, 2006).

\section{Total VFA Concentrations, Molar Proportion of VFA, Methane Production, and Hydrogen Balance}

There was interaction $(\mathrm{P}<0.01)$ between the kinds of vegetable oils and protection methods on total VFA concentration, molar proportion of VFA, methane production, and $\mathrm{H}_{2}$ utilization (Table 3, 4, and 5). The supplementation of calcium soap flaxseed oil significantly increased total VFA production, on the other hand the supplementation of microencapsulated flaxseed oil produced the highest propionate concentration and $\mathrm{H}_{2}$ utilization, the lowest A:P ratio and methane production.

The high total VFA production with supplementation of calcium soaps indicated that flaxseed oil protected with calcium soap method was able to contribute the highest energy source for ruminants. This was presumably because of flaxseed oil is high linolenic acid content (C18 : 3) compared to other oils, so that need high amount of calcium to be bound. High availability of calcium might be stimulate of the growth rumen bacterial population and their activities that will lead to increase feed fermentation. Ruckebusch \& Thivend (1980) stated that calcium plays a role in the synthesis and stability of the microbial cell wall structure and able to activate a wide range of microbial enzymes such as $\alpha$-amylase and is needed by the rumen microbes to digest cellulose. Additionally, high TDN in the ration with calcium soap flaxseed oil supplementation was potential to increase the availability of nutrients for rumen bacterial degradation process. Bhatt et al. (2013) reported that the addition of $4 \%$ rice bran oil in the form of calcium soaps in vivo can increase $(\mathrm{P}<0.05)$ total VFA production, body weight gain, body weight, dry matter intake, and lower feed conversion ratio (FCR) compared to the addition of oil in non protected or control (without the addition of oil) .

Supplementation microencapsulated flaxseed oil resulted in the lowest proportion of acetate and the ratio of $\mathrm{A}: \mathrm{P}$, and the highest proportion of propionate. This was presumably because microencapsulated flaxseed oil supplementation can stimulate the growth of bacteria propionate producers in the rumen system so that the ruminal propionate production increased. High production of propionate was correlated with low methane production and high used of $\mathrm{H}_{2}$. This was presumably because the propionate formation pathway was a ruminal metabolic pathway that used $\mathrm{H}_{2}$ (Moss et al., 2000). Thus,

Tabel 3. Total VFA production and molar proportion of VFA with different types of vegetable oil and protections method

\begin{tabular}{lcccc}
\hline \multirow{2}{*}{ Variables } & \multirow{2}{*}{ Types of vegetable oil } & \multicolumn{3}{c}{ Protections method } \\
\cline { 3 - 5 } & & Non protected & Calcium soap & Microencapsulation \\
\hline Total VFA (mM) & Sesame & $47.65 \pm 7.67^{\mathrm{DEF}}$ & $55.79 \pm 3.67^{\mathrm{CD}}$ & $52.67 \pm 10.62^{\mathrm{CDE}}$ \\
& Canola & $42.84 \pm 4.84^{\mathrm{EF}}$ & $69.84 \pm 6.15^{\mathrm{AB}}$ & $62.75 \pm 6.25^{\mathrm{BC}}$ \\
Acetate (\%) & Flaxseed & $42.02 \pm 6.19^{\mathrm{EF}}$ & $79.90 \pm 2.48^{\mathrm{A}}$ & $39.03 \pm 5.53^{\mathrm{F}}$ \\
& Sesame & $62.17 \pm 3.02^{\mathrm{A}}$ & $62.24 \pm 2.78^{\mathrm{A}}$ & $58.94 \pm 4.81^{\mathrm{AB}}$ \\
& Canola & $55.64 \pm 1.26^{\mathrm{BC}}$ & $58.49 \pm 4.44^{\mathrm{AB}}$ & $61.40 \pm 3.86^{\mathrm{A}}$ \\
Propionate (\%) & Flaxseed & $57.84 \pm 5.54^{\mathrm{ABC}}$ & $62.07 \pm 1.51^{\mathrm{A}}$ & $53.34 \pm 2.79^{\mathrm{C}}$ \\
& Sesame & $26.26 \pm 4.01^{\mathrm{C}}$ & $27.25 \pm 2.71^{\mathrm{BC}}$ & $30.04 \pm 4.96^{\mathrm{ABC}}$ \\
Butirat (\%) & Canola & $32.39 \pm 0.73^{\mathrm{A}}$ & $29.29 \pm 2.99^{\mathrm{ABC}}$ & $27.27 \pm 3.03^{\mathrm{BC}}$ \\
& Flaxseed & $30.86 \pm 4.10^{\mathrm{AB}}$ & $27.10 \pm 1.37^{\mathrm{BC}}$ & $33.22 \pm 2.31^{\mathrm{A}}$ \\
A : P & Sesame & $8.14 \pm 1.57$ & $8.11 \pm 0.59$ & $8.68 \pm 0.36$ \\
& Canola & $9.25 \pm 0.92$ & $9.07 \pm 1.13$ & $8.42 \pm 0.76$ \\
& Flaxseed & $8.67 \pm 1.45$ & $8.12 \pm 0.28$ & $9.81 \pm 0.53$ \\
& Sesame & $2.40 \pm 0.35^{\mathrm{A}}$ & $2.31 \pm 0.32^{\mathrm{AB}}$ & $2.02 \pm 0.53^{\mathrm{ABC}}$ \\
& Canola & $1.72 \pm 0.08^{\mathrm{C}}$ & $2.02 \pm 0.37^{\mathrm{ABC}}$ & $2.28 \pm 0.37^{\mathrm{AB}}$ \\
\hline
\end{tabular}

Note : Means with different superscript differ significantly $(\mathrm{P}<0.01)$. 
Tabel 4. Methane gas production from different types of vegetable oil and protections method (mol/100mol)

\begin{tabular}{lcccc}
\hline \multirow{2}{*}{ Estimation model } & \multirow{2}{*}{ Types of vegetable oil } & \multicolumn{3}{c}{ Protections method } \\
\cline { 3 - 5 } & & Non protected & Calcium soap & Microencapsulation \\
\hline Moss et al. (2000) & Sesame & $24.01 \pm 1.55^{\mathrm{A}}$ & $23.76 \pm 1.82^{\mathrm{A}}$ & $21.74 \pm 3.40^{\mathrm{ABC}}$ \\
& Canola & $19.83 \pm 0.49^{\mathrm{BC}}$ & $21.89 \pm 2.40^{\mathrm{AB}}$ & $23.50 \pm 2.27^{\mathrm{A}}$ \\
& Flaxseed & $21.01 \pm 3.09^{\mathrm{ABC}}$ & $23.73 \pm 0.94^{\mathrm{A}}$ & $18.79 \pm 1.73^{\mathrm{C}}$ \\
\hline
\end{tabular}

Note: Means with different superscript differ significantly $(\mathrm{P}<0.01)$.

Tabel 5. Hydrogen balance from different types of vegetable oil and protections method (mol/100mol)

\begin{tabular}{lcccc}
\hline \multirow{2}{*}{ Estimation model } & \multirow{2}{*}{ Types of vegetable oil } & \multicolumn{3}{c}{ Protections method } \\
\cline { 3 - 5 } & & Non protected & Calcium soap & Microencapsulation \\
\hline $\mathrm{H}_{2}$ Production & Sesame & $187.27 \pm 2.16$ & $188.98 \pm 2.00$ & $187.32 \pm 4.53$ \\
Mitsumori et al. (2012) & Canola & $186.10 \pm 1.32$ & $188.85 \pm 1.36$ & $188.18 \pm 2.00$ \\
& Flaxseed & $186.48 \pm 1.73$ & $189.13 \pm 0.83$ & $187.34 \pm 1.88$ \\
$\mathrm{H}_{2}$ Utilization & Sesame & $69.43 \pm 6.76^{\mathrm{D}}$ & $71.45 \pm 6.16^{\mathrm{CD}}$ & $78.24 \pm 10.26^{\mathrm{ABCD}}$ \\
Mitsumori et al. (2012) & Canola & $84.05 \pm 2.99^{\mathrm{AB}}$ & $77.76 \pm 8.24^{\mathrm{BCD}}$ & $72.33 \pm 7.52^{\mathrm{CD}}$ \\
& Flaxseed & $79.80 \pm 10.99^{\mathrm{ABC}}$ & $71.33 \pm 3.27^{\mathrm{CD}}$ & $87.19 \pm 5.44^{\mathrm{A}}$ \\
\hline
\end{tabular}

Note: Means with different superscript differ significantly $(\mathrm{P}<0.01)$.

it would reduce the bond of $\mathrm{H}_{2}$ and $\mathrm{CO}_{2}$ that caused $\mathrm{CH}_{4}$ production to decrease. Besides, the effect of linolenic fatty acid (C18: 3) from microencapsulated flaxseed oil was of slow release which will decrease the activity of methanogenic archae. Dan Li et al. (2012) reported that the addition of linoleic fatty acid (C18:2) and linolenic fatty acid (C18 : 3) was highly significant $(\mathrm{P}<0.01)$ in decreasing Methanobacterium formicicum population compared to the addition of oleic fatty acid. Dan Li et al. (2012) stated that anti methanogenic activity of fatty acids can be caused by the toxic effects of fatty acids on methanogens and by methanogenic competition in using $\mathrm{H} 2$ in the process of biohydrogenation of unsaturated fatty acids. Zhang et al. (2008) stated that the decrease in methane production increased with the increase of degree of unsaturated fatty acids. Czerkawski et al. (1966) reported that oleic acid with one double chain / mole could decrease methane production by 1.70 moles / mole of fatty acid. Linoleic acid with 1.72 double chain / mole could decrease methane production by 1.79 moles / mole of fatty acid and linolenic acid with 2.4 double chains / mole could decrease the methane production by 2:05 moles / mole fatty acid.

\section{CONCLUSION}

Flaxseed oil and microencapsulation method are the best vegetable oil and protection method to optimize rumen fermentation. Supplementation of microencapsulated flaxseed oil produces the highest propionate concentration and $\mathrm{H}_{2}$ utilization, the lowest $\mathrm{A}: \mathrm{P}$ ratio and methane production, and did not disturb rumen microbial activity.

\section{ACKNOWLEDGEMENT}

This experiment was funded by Directorate General of Higher Education, Ministry of National Education of Indonesia through "BOPTN" grant No. 2013. 089. 521219.

\section{REFERENCES}

Adawiah, T. Sutardi, T. Toharmat, W. Manalu, N. Ramli, \& U. H. Tanuwiria. 2007. Respons terhadap suplementasi sabun mineral dan mineral organik serta kacang kedelai sangrai pada indikator fermentabilitas ransum dalam rumen domba. Med. Pet. 30:63-70.

Agnihotri, N., R. Mishra, C. Goda, \& M. Arora. 2012. Microencapsulation-A novel approach in drug delivery: a review. Indo Global J. of Phram. Sci. 2: 1-20

Aharoni, Y., A. Orlov, A. Brosh, R. Granit, \& J. Kanner. 2005. Effect of soybean oil supplementation of high forage fatening diet on fatty acid profiles in lipid depots of fattening bull calves, and their levels of blood vitamin V. J. Anim. Feed Scie. 119: 191-202

Beauchemin, K. A., S. M. McGinn, \& H. V. Petit. 2007. Methane abatement strategies for cattle: lipid supplementation of diets. Can. J. Anim. Sci. 87: 431-440. http://dx.doi. org/10.4141/CJAS07011

Bhatt, R. S., S. A. Karim, A. Sahoo, \& A. K. Shinde. 2013. Growth performance of lambs fed diet supplemented with rice bran oil as such or as calcium soap. Asian-Aust. J. Anim. Sci. 26: 812-819.

Bhatt, R. S., N. M. Soren, M. K. Tripathi, \& S. A. Karim. 2011. Effects of different levels of coconut oil supplementation on performance, digestibility, rumen fermentation, and carcass traits of Malpura lambs. Anim. Feed Sci. and Technol. 164: 29-37. http://dx.doi.org/10.1016/j.anifeedsci.2010.11.021

Block, E., W. Chalupa, E. Evans, T. Jenkins, P. Moate, D. Palmquist, \& C. Sniffen. 2005. Calsium salts are highly digestibility. J Feedstuffs. 77 (30) : 1-7

Calvo P., T. Herna' ndez, M. Lozano, \& D. Gonza'lez-Go'mez. 2010. Microencapsulation of extra-virgin olive oil by spraydrying: Influence of wall material and olive quality. Eur. J. Lipid Sci. Technol. 112: 852-858. http://dx.doi.org/10.1002/ ejlt.201000059

Czerkawsk, J. W., K. L. Blaxter, \& F. W. Wainman. 1966. The metabolism of oleic, linoleic, and linolenic acids by sheep with reference to their effects on methane production. Br. J. 
Nutr. 20: 349-362. http://dx.doi.org/10.1079/BJN19660035

Dan Li, J. Wang, Fadi Li, Dengpan Bu. 2012. Effect of mallic acid an unsaturated fatty acid on methanogenesis and fermentation by ruminal microbiota in vitro. J. of Anim. And Vet. Advanc. 11: 2917-2922. http://dx.doi.org/10.3923/javaa.2012.2917.2922

Dehority, B. A. 2005. Effect of pH on viability of entodinium caudatum, entodinium exiguum, epidinium caudatum, and ophryoscolex purkynjei in vitro. J. of Eukaryotic Microbiol. 52: 39-342. http://dx.doi.org/10.1111/j.1550-7408.2005.00041.x

Duckett, S. K. \& M. H. Gillis. 2010. Effects of oil source and fish oil addition on ruminal biohydrogenation of fatty acids and conjugated linoleic acid formation in beef steers fed finishing diets. J Anim Sci. 88: 2684-2691. http://dx.doi. org/10.2527/jas.2009-2375

Hartadi, H., S. Reksohadiprodjo, S. Lebdosukojo, \& A. D. Tillman. 1980. Tabel Komposisi Pakan untuk Indonesia. Gajah Mada University Press, Yogyakarta.

Hristov, A. N., M. Ivan, \& T. A.McAllister. 2004. In vitro effects on individual fatty acids on protozoal numbers and on fermentation products in ruminal fluid from cattle fed a high concentrate, barley-based diet. J. Anim.Sci. 82: 2693-2704

Huang, Y., J. P. Schoonmaker, S. L. Oren, A. Trenkle, \& D. C. Beitz. 2009. Calcium salts of CLA improve availability of dietary CLA. J. Livestock Sci. 122:1-7. http://dx.doi. org/10.1016/j.livsci.2008.07.010

Jalc, D., M. Certik, K. Kundrikova, \& P. Namestkova. 2007. Effect of unsaturated C18 fatty acids (oleic, linoleic, and $\alpha$-linolenic acid) on ruminal fermentation and production of fatty acid isomers in anartificial rumen. Vet. Med. 52: 87-94.

Jenkins, T. C. 1993. Lipid metabolism in the rumen. J. Dairy Sci. 76: 3851-3863. http://dx.doi.org/10.3168/jds.S00220302(93)77727-9

Kanakdande, D., R. Bhosale, \& R. S. Singhal. 2007. Stability of cumin oleoresin microencapsulated in different combination of gum arabic, maltodextrin, and modified starch. J Carbohydrate Polymers. 67: 536-541. http://dx.doi. org/10.1016/j.carbpol.2006.06.023

Kim, C., J. Kim, Y. Oh, E. Park, G. Ahn, G. Lee, J. Lee, \& K. Park. 2009. effects of flaxseed diets on performance, carcass characteristics and fatty acid composition of hanwoo steers. Asian-Aust. J. Anim. Sci 22 (8): 1151

Kumar, R., K. Sivaiah, Y. Ramana Reddy, B. Ekambram, T. J. Reddy, \& G. V. N. Reddy. 2006. Effect of supplementation of dietary protected lipids on intake and nutrient utilization in Deccani lambs. Trop. Anim. Health Prod. 38: 151158. http://dx.doi.org/10.1007/s11250-006-4248-0

Machmüller, A. 2006. Medium-chain fatty acids and their potential to reduce methanogenesis in domestic ruminants. Agric. Ecosystems and Environment. 112: 107-114. http:// dx.doi.org/10.1016/j.agee.2005.08.010

Maia, M. R. G., L. C. Chaudhary, C. S. Bestwick, A. J. Richardson, N. McKain, T. R. Larson, I. A. Graham, \& R. J. Wallace. 2010. Toxicity of unsaturated fatty acids to the biohydrogenating ruminal bacterium Butyrivibrio fibrisolvens. J. BMC Microbiol. 10: 1-10.

Manso, T. T. Castro, A.R. Mantecon, \& V. Jimeno. 2005. Effect of palm oil and calcium soaps of palm oil fatty acids in fattening diets on digestibility, performance and chemical body composition of lambs. J. Anim. Feed Sci. 127: 175186

McDonald, P., R. A. Edward, J. F. D. Greenhalgh, \& C. A. Morgan. 2002. Animal Nutrition $6^{\text {th }}$ Edition. Scientific and Tech John Willey \& Sons. Inc, New York.

Mitsumori, M., T. Shinkai, A. Takenaka, O. Enishi, K. Higuchi, Y. Kobayashi, I. Nonaka, N. Asanuma, S. E. Denman, \& C. S. McSweeney. 2012. Responses in digestion. rumen fermentation and microbial populations to inhibition of methane formation by a halogenated methane analogue. British J. Nutr. 108: 482-491. http://dx.doi.org/10.1017/ S0007114511005794

Moss, A. R., J. P. Jouany, \& J. Newbold. 2000. Methane Production by Ruminants: Its contribution to global warming. Annal Zootechnology. 49: 231-253. http://dx.doi.org/10.1051/ animres:2000119

Ogimoto, K., \& S. Imai. 1981. Atlas of Rumen Microbiology. Japan Scientific Societes, Tokyo.

Quinn, M. J., E. R. Loe, B. E. Depenbusch, J. J. Higgins, \& J. S. Drouillard. 2008. The effect of flaxseed oil and derivatives on in vitro gas production, performance, carcas characteristics, and meat quality of finishing steers. J. The Prof Anim Sci. 24:161-168

Purushothaman, S., A. Kumar, \& D. P. Tiwari. 2008. Effect of feeding calcium salts of palm oil fatty acids on performance of lactating crossbred cows. Asian-Aust. J. Anim. Sci. 21(3): 376-385

Ramana, R.Y., N. Krishna, R. E. Raghava, \& R. T. Janardhana. 2003. Influence of dietary protected lipids on intake and digestibility of straw based diets in Deccani sheep. Anim. Feed Sci. Technol. 106: 29-38. http://dx.doi.org/10.1016/ S0377-8401(03)00064-6

Ruckebush, Y. \& P. Thievend. 1980. Digestive Physiology and Metabolism in Ruminants. Avi Publishing, Connecticut Amerika Serikat.

Sitoresmi, P. D., L. M. Yusiati, \& H. Hartadi. 2009. Pengaruh penambahan minyak kelapa, minyak biji bunga matahari, dan minyak kelapa sawit terhadap penurunan produksi metan di dalam rumen secara in vitro. Buletin Peternakan. 33: 96-105.

Steel, R. G. D. \& J. H. Torrie. 1995. Prinsip dan Prosedur Statistik Suatu Pendekatan Biometrik. PT Gramedia Pustaka Utama, Jakarta.

Tilley, J. M. A., \& R. A. Terry. 1963. A two-stage technique for the in vitro digestion of forage crops. J. British Grasslan Soc. 18: 104-111. http://dx.doi.org/10.1111/j.1365-2494.1963. tb00335.x

Wynn, R. J., Z. C. T. R. Daniel, C. L. Flux, J. Craigon, A. M. Salter, \& P. J. Buttery. 2006. Effect of feeding rumen-protected conjugated linoleic acid on carcass characteristics and fatty acid composition of sheep tissues. J. Anim. Sci 84 3440-3450. http://dx.doi.org/10.2527/jas.2006-159

Zhang, C. M., Z. Q. Guo, Y. P. Yuan, Y. M. Wu, J. K. Wang, J. K. Liu, \& W. Y. Zhu. 2008. Effect of octadeca carbon fatty acids on microbial fermentation. methanogenesis and microbial flora in vitro. Anim. Feed. Sci. Technol. 146: 259-269. http://dx.doi.org/10.1016/j.anifeedsci.2008.01.005 